\title{
Organizational Silence of Sports Specialists Working in Government Sports Organizations (Comparative Study)
}

\author{
Dena Hefny Abd Al Aziz Mamon ${ }^{1}$ \\ ${ }^{1}$ Assistant Professor, Department of Sports Management and Recreation Faculty of Physical Education for girls Helwan \\ University
}

\begin{abstract}
Research goal Degree and Differences in the degree of organizational organizational silence in the sports specialists working in sports organizations government (National Council of Sport Directorate of Youth and Sports in Cairo, The researcher used the descriptive approach in his analytical and comparative style, due to his relevance to the subject of the research, The research community included the sports specialists working in the governmental sports organizations represented in The National Council for Sport, which included (266) sports specialists divided as follows, and The Central Administration of Sports Performance and its subsidiary departments (144) are sports specialists and The Central Administration for Sports Development and its subsidiary departments (122) sports specialists, the Conclusions in study The total score of the responses of the sample members according to the value of the arithmetic average reached (232.93), ie the degree of organizational silence of the sports specialists working in the governmental organizations was higher than the average, ,The managers' fear of negative feedback was in the first order, followed by the fear of the negative reactions in the second order, Regulatory and administrative policies) in the third position, followed by (weak communication opportunities) in the fourth ranking, and finally came (after the support of senior management of organizational silence) in the last ranking
\end{abstract}

\section{Research problem and importance:}

$\mathrm{T}$ The phenomenon of organizational silence has received increasing attention from researchers, which is one of the topics of importance in modern administrative thought. It is a matter of high cost to the individual and the organization because it has many negative effects on the individual and the organization. Hence the efforts of scientists and researchers to try to limit your Organizational problem, with the aim of assisting organizations to develop, make improvements and address early to various organizational problems.

Organizational silence is referred to as the situation in which workers tend to limit their participation in providing information or ideas that express their beliefs and work experience. Organizational silence is one of the most important obstacles to the failure of knowledge management programs within different organizations. (Hasani, T., et.al.-2016)

Organizational silence in this sense prevents organizations from hearing the voices of their employees, and leads to the reluctance of many workers to share their views and lack of attention to organizational problems, at a time when organizations need a lot of interest and participation of employees, through the initiative to share information and ideas and take responsibility And responding to environmental challenges. (Amira Ahmed - 2015)

Others see it as a behavior forced on its employees because of many organizational circumstances, which has resulted in the withholding of information about the person to receive it, and the avoidance of any information or opinions on various issues and issues of labor, with the aim of deliberately limiting their participation and involvement in labor issues.

Organizational silence has many negative effects on both the individual and the organization, which is reflected in the low level of individual performance, high level of dissatisfaction, and the lack of communication between employees and between them and between the presidents, which in turn negatively affects the organization as it leads to a low level Organizational performance, lack of innovation and organizational innovation, difficulty in identifying errors, preventing early access to corruption cases, and the complexity of planning and decision- 
making processes, as a result of blocking the information. (Zeinab Abdel Razek, Zafar Nasser, 2016)

The researcher, through a review of the theoretical frameworks and previous studies in the field of organizational silence, found that it has become one of the research topics of Arab and international interest. The researchers dealt with it to study and study its effects on different aspects of organizational work, whether independently, such as Bagheri, et al.-2012), Yurdakul and others (Yurdakul, M., et.al.-2016),

Ahmed Abdulsalam (2012), or through a study Its relationship with other variables such as the study of Amira Ahmed Ibrahim (2015), and the study of Zaynab Abdul Razek, Zafar Nasser (2016), and the study of Alkn and Alkoy Akın, U. And Ulusoy.T.-2016), and Hasani and others (Hasani, T., et.al.-2016), and the study of Knolodik (Knoll, M. \& Dick, R.2013), and the study of Harbalioğlu, M. , And the study of the birth of Muhammad Milad (2015), while they abandoned the Arab Mathematical Library to the knowledge of the researcher from any of the studies that study the study of organizational silence in our sports organizations On the other hand, through direct contact with the research community of the employees of the National Council of Sport and the Directorate of Youth and Sports in Cairo, while supervising the field training for the fourth year students in sports administration,

I noticed with the students the lack of cooperation of the employees represented in the managers and sports specialists, Many of the complexity and routines that hinder the achievement of the objective of the field training process.

Through the experience of the researcher as head of complaints and suggestions committee at the Faculty of Physical Education for Girls Helwan University, she began to identify the reasons of the workers themselves, represented by the sports specialists, and found full awareness of the sports specialists in various problems and issues of work, and they have many solutions and proposals that They can effectively contribute to solving these problems, but they do not initiate any initiative to communicate these important and inspiring information to the officials, as they talk about it, conspiring, blaming and taking responsibility for the various officials with colleagues in the workplace.

This is what prompted the researcher to conduct the present study in an attempt to identify the reasons that call on the employees of the National Sports Council and the Youth and Sports Directorate in Cairo to observe the organizational silence of their organizations in order to identify its causes and avoid its negative repercussions on various aspects of organizational work.

\section{The importance of research and the need for it- :}

Organizational silence is one of the dominant administrative phenomena in the various organizations in terms of degree, intensity and scope. However, the research treatment of this variable is very small compared to its importance in organizational life, the importance of its effects on various aspects of administrative work. All administrative levels are influenced by many of the organizational characteristics and working methods.

\section{First: the theoretical importance- :}

\section{The theoretical importance of the present study is that:}

Provide the Arab Sports Library on a scale that determines the degree of organizational silence in the governmental sports organizations.

The opening of new research horizons by studying the relationship between organizational silence and many administrative variables to test the relationship or study the impact, which contributes to enriching the research field and its development through its contribution to address many administrative problems.

\section{Second: Practical importance- :}

The practical importance of the current study is as follows:

The current study of leaders and managers working in governmental sports organizations provides scientific evidence through factual data that determine the degree of organizational silence of the sports specialists and analyze its dimensions, which helps in determining its repercussions, identifying its causes and trying to treat them.

The current study of leaders and managers working in governmental sports organizations provides information that predicts the organizational silence of the governmental sports organizations in terms of its dimension (fear of the direct directors of negative feedback, poor communication opportunities, fear of negative reactions, regulations and administrative policies, Organizational structure), which increases their ability to predict organizational silence by determining the degree of one dimension. 


\section{Research Objective:}

1-Degree of organizational organizational silence in the sports specialists working in sports organizations government (National Council of Sport Directorate of Youth and Sports in Cairo.

2-Differences in the degree of organizational organizational silence in the sports specialists working in the governmental sports organizations according to the variable of the employer (National Council of Sport Directorate of Youth and Sports in Cairo

3-Differences in the degree of organizational organizational silence of sports specialists working in governmental sports organizations according to the variable years of experience.

4-Differences in organizational organizational silence according to gender variable (male - female).

5-Differences in the degree of organizational organizational silence in the sports specialists working in governmental sports organizations according to the variable level of education $(\mathrm{BA} \mathrm{MA}-\mathrm{PhD})$

6-The ability to predict the organizational silence of the governmental sports organizations in terms of its dimensions (fear of the direct leaders of negative feedback, weak communication management opportunities, fear of negative reactions, regulations and administrative policies, support of senior management of organizational silence).

\section{Research questions:}

\section{The research answers the following questions:}

1-What is the degree of organizational organizational silence among the sports specialists working in the governmental sports organizations (National Sports Council Directorate of Youth and Sports in Cairo governorate?

2-What are the differences in the organizational organizational silence of the sports specialists working in the governmental sports organizations according to the variable of the employer (National Sports Council Directorate of Youth and Sports in Cairo)?

3-What are the differences in the organizational organizational silence of the sports specialists working in the governmental sports organizations according to the variable years of experience?
4What are the differences in the organizational organizational silence of the sports specialists working in governmental sports organizations according to the gender variable (male - female)?

5-What are the differences in the organizational organizational silence of the sports specialists working in the governmental sports organizations according to the variable level of education (BA MA PhD?

6-What is the ability to predict the organizational silence of the governmental sports organizations in terms of its dimensions (fear of the direct directors of negative feedback weak communication management opportunities fear of negative reactions regulations and administrative policies support senior management of organizational silence?

\section{Terms used in research- :}

\section{Organizational silence:}

Is defined as "the tendency of the staff of the organization to prevent or avoid the provision of information or opinions, and to refrain from talking about the problems and issues of the work of the organization, and therefore limited or limited participation in these problems or issues.(Nihal Mohammed - 2014)

\section{Organizational silence of sports specialists in sports sports organizations:}

It is defined as "the reluctance of a sports specialist to be forced or optional to express any opinion, personal evaluation of the organization's policies and work issues, as a result of organizational or personal reasons, resulting in poor participation and withholding of information Procedural definition

\section{Search procedures:}

\section{Methodology used:}

The researcher used the descriptive approach in his analytical and comparative style, due to his relevance to the subject of the research.

\section{Research community:}

The research community included the sports specialists working in the governmental sports organizations represented in:

First: The National Council for Sport, which included (266) sports specialists divided as follows: 
The Central Administration of Sports Performance and its subsidiary departments (144) are sports specialists

BThe Central Administration for Sports Development and its subsidiary departments (122) sports specialists .

Second: The Directorate of Youth and Sports in Cairo Governorate (and its affiliated regions), which included 412 active sports specialists

\section{The research sample:}

It was chosen randomly by the research community, which included 220 sportsmen, 110 athletes from the National Sports Council and 110 sportsmen from the Youth and Sports Directorate in Cairo Governorate, as follows:

\section{First: Basic Research Sample:}

(120)sports specialists, divided into (60) sports specialists of the employees of the National Council of Sport, and (60) sports specialists from the staff of the Directorate of Youth and Sports in Cairo.

Second: Sample exploratory research:

(100)sports specialists, divided into (50) sports specialists of the employees of the National Council of Sport, and (50) sports specialists of the Directorate of Youth and Sports in Cairo,

\section{Data collection tools- :}

In order to collect the present study data, the researcher used the organizational silence scale of the sports specialists working in the governmental sports organizations (designed by the researcher).

\section{Statistical treatments used:}

The descriptive statistics of the sample using (mean arithmetic mean median standard deviation torsion coefficient.

Determination of stability using the A. Kronbach coefficient.

Test $(\mathrm{T})$ to denote the differences.

Analysis of variance in one direction.

The equation of L.S.D. The least significant difference.

Presentation and discussion of the results:

First: Displaying the results- :

Table (1)

Arithmetical mean, standard deviation and torsion coefficient of sample responses on the organizational silence scaleIn sports specialists working in government organizations $\mathbf{N}=\mathbf{1 2 0}$

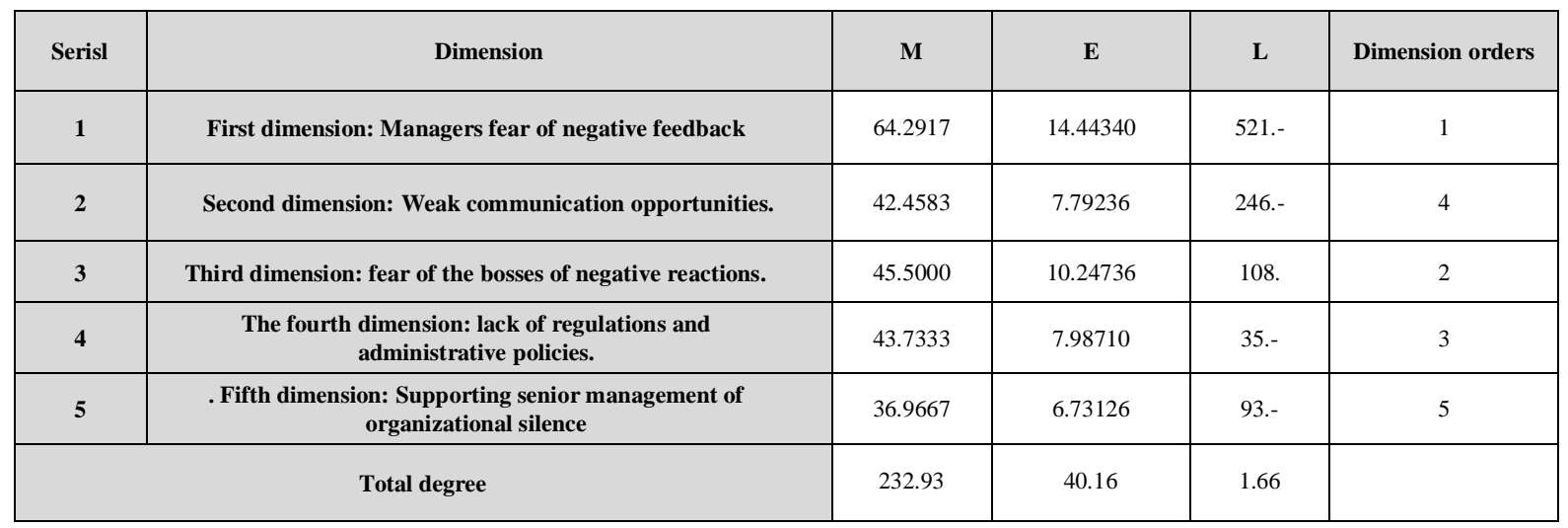

Table (1) shows the following:

The total score of the responses of the sample according to the value of the arithmetic mean was (232.93), ie the degree of organizational silence of the sports specialists working in the governmental organizations came above the average.
The dimensions can be arranged according to the arithmetic mean value of the sample responses on the dimensions of the scale in descending order. The managers' fear of negative feedback came in the first order, followed by the fear of the managers of the negative 
reactions in the second order, And administrative policies) in the third position, while after (weak communication opportunities) in the fourth ranking, and finally came after (support the senior management of organizational silence) in the last order.

Table (2)

Differences between sports specialists working in government sports organizations In accordance with the work towards their response to the dimensions of the measure of organizational silence $N=120$

\begin{tabular}{|c|c|c|c|c|c|c|c|}
\hline \multirow{2}{*}{ Serial } & \multirow{2}{*}{ dimension } & \multicolumn{2}{|c|}{$\begin{array}{c}\text { Directorate of Youth } \\
\text { and Sports } n=60\end{array}$} & \multicolumn{2}{|c|}{$\begin{array}{c}\text { National Council of } \\
\text { Sport } \mathbf{N}=60\end{array}$} & \multirow[t]{2}{*}{$\mathbf{T}$} & \multirow{2}{*}{ Significance } \\
\hline & & $\mathbf{m}$ & $\mathbf{e}$ & $\mathbf{m}$ & $\mathbf{E}$ & & \\
\hline 1 & $\begin{array}{c}\text { First dimension: Managers fear of negative } \\
\text { feedback }\end{array}$ & 70.88 & 10.61 & 69.61 & 9.95 & 674. & 501. \\
\hline 2 & $\begin{array}{c}\text { Second dimension: Weak communication } \\
\text { opportunities. }\end{array}$ & 46.90 & 5.99 & 44.78 & 6.68 & 1.82 & 070. \\
\hline 3 & $\begin{array}{c}\text { Third dimension: fear of the bosses of } \\
\text { negative reactions. }\end{array}$ & 53.93 & 7.22 & 54.33 & 5.89 & 332. & 740. \\
\hline 4 & $\begin{array}{l}\text { The fourth dimension: lack of regulations and } \\
\text { administrative policies. }\end{array}$ & 52.88 & 2.27 & 52.45 & 2.55 & 982. & 328. \\
\hline 5 & $\begin{array}{l}\text {. Fifth dimension: Supporting senior } \\
\text { management of organizational silence }\end{array}$ & 40.16 & 5.32 & 38.36 & 6.35 & 1.68 & 095. \\
\hline & Total degree & & 264.76 & 18.97 & 259.55 & 20.31 & 1.45 \\
\hline
\end{tabular}

*Significance.

Table (2) shows that: There were no statistically organizational silence scale, as well as the total score of significant differences between the sports specialists the scale. working in the Directorate of Youth and Sport, and the sports specialists working in the National Sports Council, in the degree of their response to the dimensions of the

Table (3)

Analysis of the variance between the sample of sports specialists working in governmental sports organizations according to years of experience and their response to the dimensions of the organizational silence scale $\mathbf{N}=120$

\begin{tabular}{|c|c|c|c|c|c|c|}
\hline Dimensions & Source of contrast & Total squares & d.h. & Average squares & $\mathbf{F}$ & $\begin{array}{l}\text { Significa } \\
\text { nce }\end{array}$ \\
\hline $\begin{array}{l}\text { First dimension: Managers } \\
\text { fear of negative feedback }\end{array}$ & Between groups & 10777.57 & 3 & 3592.52 & $44.28^{*}$ & 000. \\
\hline \multirow{2}{*}{$\begin{array}{c}\text { Second dimension: Weak } \\
\text { communication } \\
\text { opportunities. }\end{array}$} & Between groups & 3799.41 & 3 & 1266.47 & \multirow{2}{*}{$41.01^{*}$} & \multirow{2}{*}{000.} \\
\hline & Within groups & 3582.05 & 166 & 30.88 & & \\
\hline \multirow{2}{*}{$\begin{array}{l}\text { Third dimension: fear of the } \\
\text { bosses of negative reactions. }\end{array}$} & Between groups & 10191.93 & 3 & 3397.31 & \multirow{2}{*}{$134.99 *$} & \multirow{2}{*}{000.} \\
\hline & Within groups & 2919.36 & 116 & 25.16 & & \\
\hline \multirow{2}{*}{$\begin{array}{c}\text { The fourth dimension: lack } \\
\text { of regulations and } \\
\text { administrative policies. }\end{array}$} & Between groups & 5242.29 & 3 & 1747.43 & \multirow{2}{*}{$82.42^{*}$} & \multirow{2}{*}{000.} \\
\hline & Within groups & 2459.29 & 116 & 21.20 & & \\
\hline $\begin{array}{l}\text {. Fifth dimension: } \\
\text { Supporting senior } \\
\text { management of } \\
\text { organizational silence }\end{array}$ & Between groups & 2258.16 & 3 & 752.72 & $25.88^{*}$ & 000. \\
\hline \multirow{2}{*}{ Total degree } & Between groups & 147134.33 & 3 & 49044.77 & \multirow{2}{*}{$214.63^{*}$} & \multirow{2}{*}{000.} \\
\hline & Within groups & 26506.65 & 116 & 228.50 & & \\
\hline
\end{tabular}

*Significance.

It is clear from Table (3) that: There are statistically significant differences between the sports specialists working in the governmental sports organizations in their response to the dimensions of the organizational silence scale according to the years of experience (third degree, second grade, first degree, major). (4) The following illustrates this. 
Table (4)

The significance of differences between the sample of sports specialists working in governmental sports organizations according to the years of experience towards their response to the dimensions of the measure of organizational silence $N=120$



Table (4) shows the following: There are statistically significant differences between the athletes working in the first and third degrees and the major specialists in the degree of their response to all dimensions of the scale as well as the total score of the measure of organizational silence, for the benefit of sports specialists working primarily.
There are also statistically significant differences between both the second and third level sports specialists and the major specialists in the degree of their response to all dimensions of the scale as well as the total score of the organizational silence scale for the benefit of second-class sports specialists. 
Table (5)

Differences between sports specialists employed by governmental sports organizations according to gender (male / female) towards their response to the dimensions of the organizational silence scale $\mathbf{N}=\mathbf{1 2 0}$

\begin{tabular}{|c|c|c|c|c|c|c|c|}
\hline \multirow{2}{*}{ Serial } & \multirow{2}{*}{ Dimensions } & \multicolumn{2}{|c|}{ Males $(n=63)$} & \multicolumn{2}{|c|}{ Females $(n=57)$} & \multirow{2}{*}{$\mathbf{T}$} & \multirow{2}{*}{ Significance } \\
\hline & & $\mathbf{m}$ & e & m & $\mathbf{E}$ & & \\
\hline 1 & $\begin{array}{l}\text { First dimension: Managers fear of negative } \\
\text { feedback }\end{array}$ & 67.98 & 10.02 & 58.98 & 9.99 & $4.91 *$ & 000. \\
\hline 2 & $\begin{array}{l}\text { Second dimension: Weak communication } \\
\text { opportunities. }\end{array}$ & 44.17 & 7.14 & 39.36 & 6.25 & $3.90 *$ & 000. \\
\hline 3 & $\begin{array}{l}\text { Third dimension: fear of the bosses of } \\
\text { negative reactions. }\end{array}$ & 52.47 & 6.98 & 47.35 & 6.00 & $4.28 *$ & 000. \\
\hline 4 & $\begin{array}{l}\text { The fourth dimension is the lack of } \\
\text { regulations and administrative policies }\end{array}$ & 52.71 & 2.35 & 49.82 & 5.15 & $4.01 *$ & 000. \\
\hline 5 & $\begin{array}{c}\text { Fifth dimension: Supporting senior } \\
\text { management }\end{array}$ & 38.23 & 6.24 & 34.50 & 7.72 & $2.92 *$ & 000. \\
\hline & Total degree & 255.58 & 21.15 & 230.03 & 17.91 & $7.10 *$ & 000. \\
\hline
\end{tabular}

$0>5 *$.Significance.

Table (5) shows that: There are statistically significant differences between the sports specialists employed in the dimensions of the scale, as well as the total score of the scale. governmental sports organizations in their response to the dimensions of the organizational silence scale according to gender (males and females) in favor of males in all

Table (6)

Analysis of the variation between the sample of sports specialists working in governmental sports organizations according to the level of education and their response to the dimensions of the organizational silence scale $N=120$

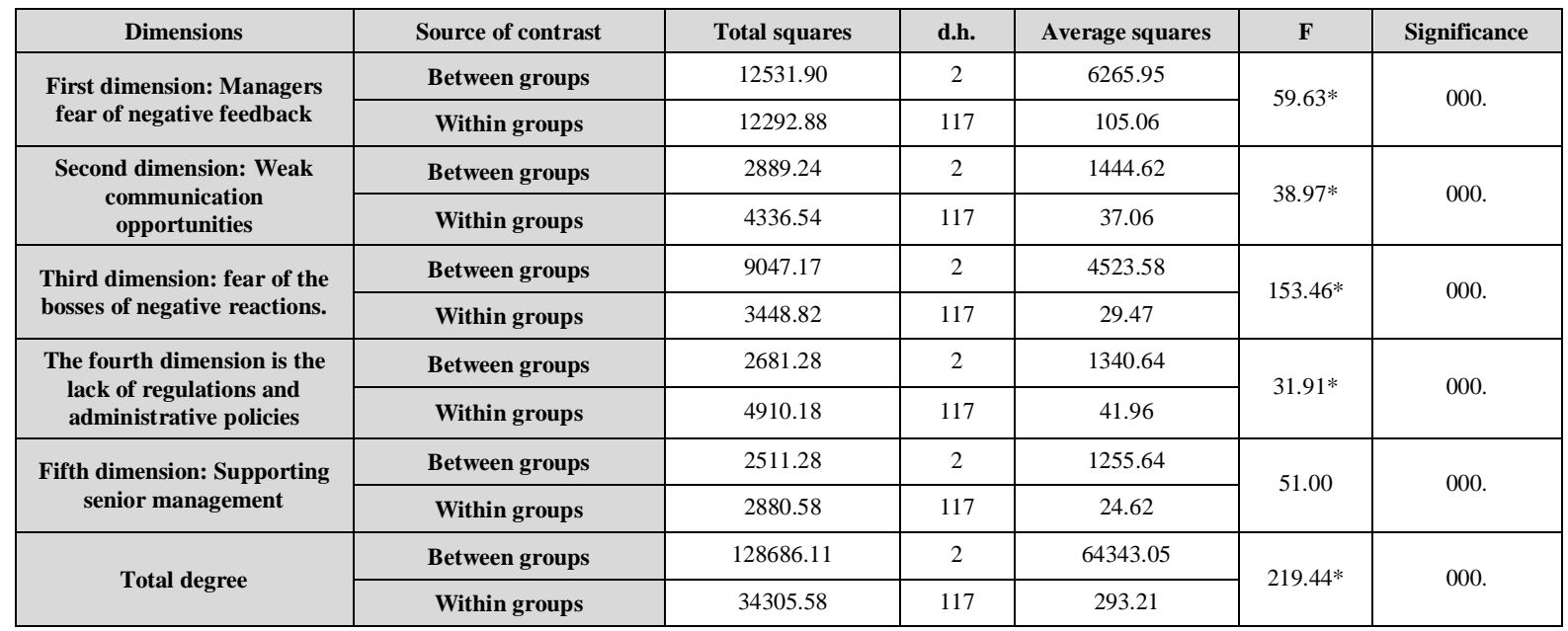

*Significance.05>

It is clear from Table (6) that: There are statistically significant differences between the sports specialists working in the governmental sports organizations in the degree of their response to the dimensions of the organizational silence scale according to the level of education (BA M.Sc. PhD). To calculate the significance of differences, LSE is calculated as the least significant difference and Table (7) So. 
Table (7)

The significance of differences between the sample of sports specialists working in governmental sports organizations according to the level of education towards their response to the dimensions of organizational silence scale $\mathbf{N}=\mathbf{1 2 0}$

\begin{tabular}{|c|c|c|c|c|c|}
\hline Dimensions & Statement & SMA & BA & M.A. & Ph.D \\
\hline \multirow{3}{*}{$\begin{array}{l}\text { First dimension: Managers fear of negative } \\
\text { feedback }\end{array}$} & BA & 75.21 & & $20.28 *$ & $20.88^{*}$ \\
\hline & MA & 54.93 & & & 596. \\
\hline & $\mathrm{PhD}$ & 54.33 & & & \\
\hline \multirow{3}{*}{$\begin{array}{c}\text { Second dimension: Weak communication } \\
\text { opportunities }\end{array}$} & $\mathrm{BA}$ & 47.55 & & $8.43^{*}$ & $11.83^{*}$ \\
\hline & MA & 39.11 & & & $3.40^{*}$ \\
\hline & $\mathrm{PhD}$ & 35.71 & & & \\
\hline \multirow{3}{*}{$\begin{array}{l}\text { Third dimension: fear of the bosses of } \\
\text { negative reactions. }\end{array}$} & $\mathrm{BA}$ & 54.73 & & $18.17^{*}$ & $15.54 *$ \\
\hline & MA & 36.55 & & & $2.63-$ \\
\hline & $\mathrm{PhD}$ & 39.19 & & & \\
\hline \multirow{3}{*}{$\begin{array}{l}\text { The fourth dimension is the lack of } \\
\text { regulations and administrative policies }\end{array}$} & $\mathrm{BA}$ & 48.58 & & $10.35^{*}$ & $6.54^{*}$ \\
\hline & MA & 38.23 & & & $3.81-*$ \\
\hline & $\mathrm{PhD}$ & 42.04 & & & \\
\hline \multirow{3}{*}{$\begin{array}{c}\text { Fifth dimension: Supporting senior } \\
\text { management }\end{array}$} & $\mathrm{BA}$ & 41.85 & & $9.18^{*}$ & $9.14 *$ \\
\hline & MA & 32.67 & & & 039.- \\
\hline & $\mathrm{PhD}$ & 32.71 & & & \\
\hline \multirow{3}{*}{ Total degree } & BA & 267.94 & & $66.43^{*}$ & $63.94 *$ \\
\hline & MA & 201.51 & & & $2.48-$ \\
\hline & $\mathrm{PhD}$ & 204.00 & & & \\
\hline
\end{tabular}

Table (7) shows the following: There are statistically significant differences between the athletes who obtained the bachelor's, master's and doctorate degrees in the degree of their response to the expressions of the first dimension (managers fear of negative feedback) for the benefit of the sports specialists who have a bachelor's degree.

There are statistically significant differences between the athletes who obtained the bachelor's and master's degrees and the doctorate in the degree of their response to the second dimension (weakness of communication opportunities) for the benefit of the sports specialists who have a bachelor's degree.

There are statistically significant differences between the athletes who have the masters and the doctorate in the degree of their response to the second dimension (weak communication opportunities) for the benefit of the sports specialists who have a master's degree.

There are statistically significant differences between the athletes who obtained the bachelor's and master's degrees and the doctorate in the degree of their response to the expressions of the third dimension (fear of the heads of negative reactions), in favor of sports specialists who have a bachelor's degree.

There are statistically significant differences between the athletes who obtained the bachelor's, master's and doctorate degrees in the degree of their response to the fourth dimension phrases (lack of regulations and administrative policies) for the benefit of the sports specialists who have a bachelor's degree.

There are statistically significant differences between the athletes who obtained the bachelor's, master's and doctorate degrees in the degree of their response to the fourth dimension phrases (lack of regulations and administrative policies) for the benefit of the sports specialists who have a bachelor's degree.

There are statistically significant differences between the athletes who obtained the bachelor's, master's and doctorate degrees in the degree of their response to the expressions of the fifth dimension (support the senior management of organizational silence) for the benefit of the sports specialists who have a bachelor's degree.

There are statistically significant differences between the athletes who obtained the bachelor's, master's and doctorate degrees in the degree of their response to the expressions of organizational silence scale (the scale as a whole), in favor of the sports specialists who have a bachelor's degree. 
Table (8)

Analysis of the linear regression of the dimensional contribution of achieving organizational silence Governmental sports organizations $N=120$

\begin{tabular}{|c|c|c|c|c|c|c|c|c|c|}
\hline \multirow[b]{2}{*}{ Step } & \multirow[b]{2}{*}{$\begin{array}{c}\text { Fixed } \\
\text { amount }\end{array}$} & \multirow[b]{2}{*}{$\begin{array}{l}\text { Standar } \\
\text { d error }\end{array}$} & \multicolumn{6}{|c|}{ Contributing variables and slope coefficients } & \multirow[b]{2}{*}{$\begin{array}{c}\text { Contrib } \\
\text { ution } \\
\text { Ratio }\end{array}$} \\
\hline & & & $\mathbf{F}$ & $\begin{array}{c}\text { Managers } \\
\text { fear of } \\
\text { negative } \\
\text { feedback }\end{array}$ & $\begin{array}{c}\text { Fear of the } \\
\text { bosses of } \\
\text { negative } \\
\text { reactions }\end{array}$ & $\begin{array}{c}\text { Support } \\
\text { senior } \\
\text { management } \\
\text { of } \\
\text { organizationa } \\
\text { I silence }\end{array}$ & $\begin{array}{c}\text { Weak } \\
\text { commu } \\
\text { nication } \\
\text { opportu } \\
\text { nities }\end{array}$ & $\begin{array}{c}\text { Lack of } \\
\text { regulations } \\
\text { and } \\
\text { administrati } \\
\text { ve policies }\end{array}$ & \\
\hline 1 & 173.78 & 10.21 & 92.42 & 10.13 & - & - & - & - & $66.3 \%$ \\
\hline 2 & 115.46 & 7.61 & 130.70 & 1.18 & 1.29 & - & & - & $83.1 \%$ \\
\hline 3 & 75.81 & 4.97 & 257.21 & 1.03 & 1.23 & 1.21 & - & - & $93.2 \%$ \\
\hline 4 & 45.90 & 3.26 & 487.08 & 1.04 & 1.17 & 1.04 & 885. & - & $97.2 \%$ \\
\hline 5 & 016. & 000. & - & 1.0 & 1.0 & 1.0 & 1.0 & 1.0 & $100 \%$ \\
\hline
\end{tabular}

Table (8) shows the following: All dimensions of organizational silence have a contribution rate in the total score of the measure of organizational silence of the sports specialists working in governmental organizations.

The organizational silence dimensions can be arranged in descending order according to the percentage of their contribution as follows:

The first contributing dimension is managers' fear of negative feedback, with a contribution of $66.3 \%$.

The second contributing dimension is (fear of the heads of negative reactions) with a contribution rate of $(16.8 \%)$ to raise the proportion of the contribution of each of the managers after fear of negative feedback, and after the fear of the heads of negative reactions in the total score of the measure of organizational silence of sports specialists working Of government organizations to $(83.1 \%)$.

The third contributing dimension is (supporting the senior management of organizational silence) with a contribution rate of $(10.1 \%)$ to increase the percentage of the contribution of both after the managers' fear of negative feedback, after the fear of the principals of the negative reactions and after the support of the senior management of organizational silence in the total score of the scale The organizational silence of the sports specialists working in governmental organizations $(93.2 \%)$.

The fourth contributory dimension is (weak communication opportunities) with a contribution rate of $4 \%$ to increase the contribution of both managers' fear of negative feedback, after the fear of the negative feedback, and after the support of the senior management of organizational silence. The total degree of organizational silence of the sports specialists working in governmental organizations to $(97.2 \%)$.

The fifth contributory dimension is (regulatory and administrative deficiencies) with a contribution of (2.8\%) to increase the contribution of both managers' fear of negative feedback, after the fear of negative feedback from managers, and after the support of senior management of organizational silence, , And after the lack of regulations and administrative policies, in the overall degree of the organizational silence of the sports specialists working in governmental organizations to $(100 \%)$.

The following prediction equation can be inferred:

$\mathrm{Y}=\mathrm{a}+\mathrm{b} 1 \mathrm{x} 1+\mathrm{b} 2 \times 2+\mathrm{b} 3 \times 3+\mathrm{b} 4 \times 4+\mathrm{b} 5 \times 5$.

Where: $\mathrm{Y} \rightarrow$ (dependent variable) is the total score of the organizational silence of the governmental sports organizations

$: \mathrm{a} \rightarrow$ Fixed amount.

$\mathrm{:} \mathrm{b} \rightarrow$ Contributing variable (dimensions of organizational silence

$: \mathrm{x} \rightarrow$ correlation coefficient.

Organizational silence of sports specialists in government organizations

$\times(1+)$ Managers' fear of negative feedback $(+) \times 1 \times$ Fear of managers of negative feedback $+1 \times$ Support of senior management of organizational silence $+1 \times$ Double communication opportunities $+1 \times$ Lack of regulatory regulations and administrative policies

Second: Discussion of the results: 


\section{Discuss the first question:}

The results of the study in the field of identification of the organizational silence of the sports specialists in the sports sports organizations (National Sports Council Directorate of Youth and Sports in Cairo Governorate) as shown in Table (1), that the total score of the responses of the sample according to the value of the arithmetic average reached (232.93) .

The dimensions were calculated according to the value of the arithmetic average of the sample responses on the dimensions of the scale. The managers' fear of negative feedback came in the first order, followed by the fear of the heads of negative reactions in the second order, (The lack of regulatory opportunities and administrative policies) in the third position, while (weak communication opportunities) came in fourth place, and finally came (after the senior management support of organizational silence) in the last ranking.

The results of the present study are consistent with the results of the Ak1n and Ulusoy.T.-2016 study, where moderate degrees of organizational silence were found among academics working in government universities in Turkey.

The results of the present study are consistent with the results of the study of Zaynab Abdul Razzaq and Zafar Nasser (2016). The organizational silence of the staff of the Babil University Presidency came to a moderate degree, while in the order of dimensions, Fear of isolation lack of experience fear of damaging relationships workrelated concerns organizational and administrative factors

The findings of the present study are consistent with the results of Leyva-Moral, J.-2015. The main findings of the study are that the main reasons for organizational silence are occupational alienation among workers and fear of senior management. The organizational silence negatively affects the process. Decision making.

The results of the present study also agree with the results of the study of the birth of Muhammad (2015), where he reached the dimensions of the organizational silence of the employees of the government sector at the University of Sirte in Libya came to a medium degree

while the results of the current study differ with the results of the study of both Yorda Cole and others

Yurdakul, M., etal.-2016), where it was concluded that the organizational silence of the Turkish health sector was high, and that workers remained silent on issues of ethics and responsibility.

The results of the current study are also different from those of Yurdakul, M., et al.-2016, where it was found that the organizational silence in the Turkish health sector was high, and that workers remain silent in issues related to morality and responsibility. Issues of risk in the Turkish health sector because of the sensitivity of unreported errors and the risks involved.

The results of the current study also differ with the results of the study of Henrxin and Dayton

(Henriksen, K. \& Dayton, E.-2015). They concluded that there are three main factors contributing to organizational silence in organizations: individual factors such as personal characteristics of individuals, self-interest, social factors and associated concepts of responsibility, , Organizational factors, organizational structures, communication level and management style.

The researcher believes that the existence of organizational silence higher than average in the sample is due to several reasons, including:

1-The unwillingness of managers to receive any information from the sports specialists on the progress of their work and the level of their decisions and achievement, as a result of concern about the occurrence of organizational chaos.

2-Lack of openness and information partnership between managers and sports specialists, by the lack of involvement in the issues that are discussed and decisions that are taken, which leaves them feeling the ability to effectively express their views and proposals effectively

3-the unwillingness of the sports specialists to express their views or the participation of the authorities responsible for their information, because of the expectation of harm.

4-There is a deficit in the set of general legal rules and values and binding principles, which govern the actions of managers and sports specialists and their decisions, to meet the needs of workers and their sense of safety and freedom.

Thus, the first question has been answered

"What is the organizational organizational silence of the sports specialists working in the governmental sports 
organizations?" (National Sports Council Youth and Sports Directorate in Cairo?

\section{Discuss the second question:}

The results of the study in the field of recognition of differences in the degree of organizational organizational silence in the sports specialists working in the governmental sports organizations according to the variable of the employer (National Sports Council Directorate of Youth and Sports in Cairo Governorate) as shown in Table (2), that there are no differences of statistical significance Among the sports specialists working in the Directorate of Youth and Sports in Cairo Governorate, and the sports specialists working in the National Sports Council, in the degree of their response to the dimensions of the measure of organizational silence, as well as the total score of the scale

The results of the present study differ with the results of the study of Abdullah Mohammed (2014). There were significant differences in the degree of organizational silence among the employees in the government departments in $\mathrm{Al}-\mathrm{Q}$ assim region according to the variable of the employer.

The results of the present study are also different from the results of the study of Ahmed Abdel Salam (2012), where there was a significant difference between workers in public and private sector organizations in Egypt in the degree of organizational silence in favor of workers in public sector organizations.

The results of the present study are also different from the results of the study of Nikmaram and S. Nikolam, S., et.al.-2012). The most important results are the existence of statistically significant differences in the degree of organizational silence of faculty members working in different faculties of humanities and administration In Iran.

The researcher finds that the absence of statistically significant differences between the sports specialists working in the directorate of youth and sports in Cairo governorate, and the sports specialists working in the National Sports Council in the degree of their response to the dimensions of the organizational silence scale as well as the overall score of the measure is due to the similar working conditions in the Directorate Youth and Sport and the National Sports Council for two main reasons:

1-The Directorate of Youth and Sports in Cairo Governorate and the National Sports Council is a governmental organization that is similar in regulations and laws governing the conditions of work and workers.

2-The Directorate of Youth and Sports in Cairo Governorate is an organization affiliated to the National Council for Sport. It also implements many of its plans, programs and activities. The Directorate also plans and implements programs and activities aimed at achieving some of the objectives of the National Sports Council in the governorate of Cairo.

Thus, the second question has been answered

"What are the differences in the degree of organizational organizational silence in the sports specialists working in governmental sports organizations according to the variable of the employer (National Council of Sport Directorate of Youth and Sports in Cairo"?

\section{Discussion of the third question:}

The results of the study in the field of recognition of differences in the degree of organizational organizational silence in the sports specialists working in the governmental sports organizations according to the variable years of experience, as shown in Table (3.4), there are differences of statistical significance between both the sports specialists working in the first and degree (The scale as a whole) for the benefit of the sports specialists working in the first place, and there are differences of statistical significance between each of the specialists in the sports world Second and third degree laxative and the top specialist in the degree of their response to all dimensions of the scale as well as the total score of the organizational silence scale (the scale as a whole), in favor of second-class sports specialists

The results of the present study are consistent with the results of the study of Ahmed Abdel Salam (2012), where he found that there are statistically significant differences between workers in public and private sector organizations in Egypt in the degree of organizational silence according to years of experience in favor of less experienced workers.

The results of the present study differ with the results of the study of Amira Ahmed (2015) where it reached the absence of statistical differences between the employees of the Directorate of Education in Dakahlia governorate in the degree of organizational silence according to the variable years of experience. 
The results of the present study are also different from the results of the CAVERSI and DIMARTAS studies

(Kahveci, G., Demirtaş, Z.2014). The most important results are that there are statistically significant differences in the degree of organizational silence of the administrators and teachers of primary schools in Elazig in the academic year 2009-2010 according to years of experience (less than six years) six years and more) for the two students who have served for more than six years.

The researcher believes that the access of sports specialists with less experience to high grades in their response to the measure of organizational silence is due to the fact that they prefer to conduct silence in their organizations due to several reasons, including:

1-Athletes with less experienced experience are keen to win the loyalty and confidence of their colleagues and bosses in the work, which makes them prefer to silence on various issues, which is often a kind of consent and implicit consent to various situations and organizational decisions.

2-Lack of confidence of sports specialists with less experience in their expertise and abilities, which makes them reluctant to share their views on problems and issues of work.

3-The concern of sports specialists with less experience of making mistakes affect the appreciation of their colleagues and bosses in the work to them due to lack of experience and experience in the field of work.

4-Fear of sports specialists with less experience in some subjects so as not to cause physical or moral harm to those around them (managers and colleagues) as a kind of protection.

Thus, the third question has been answered

"What are the differences in the organizational organizational silence of sports specialists working in government sports organizations according to the variable years of experience"?

\section{Discussion of the fourth question:}

The results of the study in the field of identifying the differences in the organizational organizational silence in the sports specialists in the governmental sports organizations according to the gender variable as shown in Table (5) indicate that there are statistically significant differences between the sports specialists working in the governmental sports organizations, In the degree of their response to the dimensions of the measure of organizational silence according to gender (male female) in favor of males in all dimensions of the scale, as well as the total score of the scale, which means that males have high degrees of organizational silence, in each dimension of the scale as well as in the total score to For a scale.

The results of the present study are consistent with the results of the study of Alaa Ahmed (2016) where he found that there are no statistically significant differences between the responses of workers in the governmental sector hospitals in Delta governorates towards the dimensions of organizational silence according to the gender variable (male female.

The results of the present study are in line with the results of the Amira Ahmed study (2015), where there were significant statistical differences between the male directors and the female directors in the Directorate of Education in Dakahlia governorate in the degree of organizational silence in the dimension of supervisors' attitudes towards silence.

The results of the present study are consistent with the results of the study of Ahmed Abdel Salam (2012), where he found that there are no statistically significant differences in the degree of organizational silence among workers in public and private sector organizations in Egypt according to gender.

The results of the current study differ with the results of the study of Caversi and Demertas

(Kahveci, G., Demirtaş, Z.2014). The most important results are that there are statistically significant differences in the degree of organizational silence among the administrators and teachers of primary schools in Elazig in the academic year 2009-2010 according to gender variable For females.

The results of the current study are also different from the results of the study of Milda Harpogloua and others

(Harbalioğlu, M., et.al.-2014), where there were statistically significant differences between the staff at Kellis University of Arlik in Turkey and the degree of organizational silence according to the gender variable (male-female) for females.

The researcher considers that the high degree of organizational silence in male sports specialists is due to 
forced or selective reluctance to express any form of opinion and personal evaluation of the organization's policies and labor issues due to organizational or personal reasons.

1-Male sports specialists are more concerned with females in maintaining their jobs, especially in the harsh economic conditions of the country and the difficulty of obtaining another job in the country or abroad.

2-Male sports specialists are more likely than females to provide a calm work environment free of squabbles with colleagues or superiors, allowing them to facilitate work according to their circumstances. Many of them have more than one job.

3-Male sports professionals are more willing than females to get promotions in their jobs by establishing good relations with their bosses, showing satisfaction and loyalty and agreeing with their opinions and decisions. Those who seek positions and gains are usually in line with the administration and do not differ in order to satisfy them.

4-Male sports specialists are more experienced than females in matters of work, procedures, mechanisms and problems, and more understanding of the official and informal authorities, which provides them with more information of the needs of the work and the circumstances of the various decisions. This reduces the volume of their complaints or criticism of the working conditions and problems and decisions.

Thus, the answer to the fourth question of research, which states:

What are the differences in the organizational organizational silence of sports specialists working in government sports organizations according to the gender variable"?

\section{Discuss the fifth question:}

The results of the study in the field of recognition of differences in the degree of organizational organizational silence in the sports specialists working in governmental sports organizations according to the variable level of education (BA MA PhD) as shown in Table $(6,7)$, there are differences of statistical significance between Athletes with bachelor's, master's and doctorate degrees in the degree of their response to the expressions of each dimension of the measure of organizational silence for the benefit of sports specialists with a bachelor's degree, and there are differences of statistical significance between both sports specialists who obtained the Kalorios and master's and doctoral degrees in their response on a scale of silence organizational as a whole for the benefit of specialists athletes who obtained a bachelor.

The results of the present study are consistent with the results of the study of Alaa Ahmed (2016) where he found that there are statistically significant differences between the responses of workers in the government sector hospitals in the governorates of Delta to the dimensions of organizational silence according to the variable level of education.

The results of the current study differ with the results of the study of Amira Ahmed (2015) where it was found that there are statistically significant differences between the educational levels in the organizational silence variable in the staff of the Directorate of Education in Dakahlia governorate for the benefit of higher educational levels.

The results of the current study differ with the results of a study

(Harbalioğlu, M., et.al.-2014), where there were statistically significant differences between the staff at Kellis University of Arlik in Turkey and the degree of organizational silence according to the variable level of education (BA MA PhD) in favor of Higher educational level.

The researcher believes that this is due to the reluctance of sports specialists who have a bachelor's degree mandatory or optional for any form of expression of their views, or to offer their personal evaluation on the policies of the organization and labor issues, due to organizational or personal reasons, for several reasons, including:

The reluctance of managers to receive any information from the sports specialists who have a bachelor's degree on the progress of their work and the level of their decisions and achievement, as a result of concern about the weakness of their professional abilities and lack of experience or fear of organizational chaos as a result of being criticized two workers are often characterized by modern appointment

Lack of openness and information partnership between managers and sports specialists who have a bachelor's degree, which leads to weak involvement in the issues that are discussed and decisions taken as a result of the lack of confidence of senior management in their abilities, which 
leaves them feeling effective ability to express their views and proposals effectively.

The unwillingness of the mathematical specialists who have a bachelor's degree to express their opinion or the participation of the authorities responsible for their information because of the expectation that they will be subjected to physical or moral harm (deduction, exclusion, persecution, neglect, etc.) by their presidents as a result of their creation or adoption of the opinion. Or take a particular position on labor issues, while they need the satisfaction and confidence of their superiors so that they can have many advantages that help them draw their professional path, and understand their details away from the complexities resulting from conflicts and disagreements with presidents.

Thus the answer to the fifth question of the research, which states:

"What are the differences in the organizational organizational silence of the sports specialists working in the governmental sports organizations according to the variable level of education (BA MA - PhD?

\section{Discuss the sixth question:}

The results of the study indicate the ability to predict the organizational silence of the governmental sports organizations in terms of its dimension (fear of direct supervisors of negative feedback, poor management communication opportunities, fear of negative reactions, regulations and administrative policies, support of senior management of organizational silence) Table (8): All dimensions of organizational silence have a contribution rate in the total score of the organizational silence scale among the sports specialists working in governmental organizations.

The results of the study in the field of recognition of the ability to predict the organizational silence of the governmental sports organizations in terms of its dimension (fear of the direct directors of negative feedback, weak management communication opportunities, fear of negative reactions, regulations and administrative policies, , The following prediction equation can be inferred:

$\mathrm{Y}=\mathrm{a}+\mathrm{b} 1 \times 1+\mathrm{b} 2 \times 2+\mathrm{b} 3 \times 3+\mathrm{b} 4 \times 4+\mathrm{b} 5 \times 5$.

Where: $\mathrm{Y} \rightarrow$ (dependent variable) is the total score of the organizational silence of the governmental sports organizations
$: \mathrm{a} \rightarrow$ Fixed amount.

$: \mathrm{b} \rightarrow$ Contributing variable (dimensions of organizational silence

$: \mathrm{x} \rightarrow$ correlation coefficient.

Organizational silence of sports specialists in government organizations

$\times(1+)$ Managers' fear of negative feedback $(+) \times 1 \times$ Fear of managers of negative feedback $+1 \times$ Support of senior management of organizational silence $+1 \times$ Double communication opportunities $+1 \times$ Lack of regulatory regulations and administrative policies

which means that the equation can be used to predict the level of organizational silence in the governmental sports organizations by the five variables.

The results of the current study differ with the results of the study of Ahmed Abdel Salam (2012), where he found that the strongest predictors of the behavior of organizational silence in public and private sector organizations in Egypt are the supervisor's attitudes towards silence.

The researcher believes that obtaining the "managers fear of negative feedback" at the highest rate of contribution to the degree of organizational silence in the organizations of sports among the dimensions of organizational silence can be attributed to the fact that sports specialists working in government sports organizations believe that their managers are influenced by their professional performance in several beliefs, Which have had a negative impact led to increase the degree of silence of the organization of sports specialists, including:

Managers view their decisions as right, and believe that the sports specialists working in these organizations are trying to detract from their abilities.

Managers believe that they have high management skills, and take the observations of sports specialists to work as a criticism of their own.

Managers feel embarrassed when sports specialists draw their attention to work errors, as they think they can not afford to work.

Managers only have data and information to make decisions, and think that sports specialists are trying to 
show their shortcomings in front of others when trying to express their views.

Sports sports managers feel that their views on work are not correct, and that the difference of opinion on labor issues is not useful

\section{Thus, the sixth question of the research was answered}

"What is the ability to predict the organizational silence of governmental sports organizations in terms of its dimensions (fear of direct directors of negative feedback, poor management communication opportunities, fear of negative reactions, regulations and administrative policies, support of senior management of organizational silence"?

\section{Conclusions:}

1- The total score of the responses of the sample members according to the value of the arithmetic average reached (232.93), ie the degree of organizational silence of the sports specialists working in the governmental organizations was higher than the average.

2- The dimensions of the mean of the sample responses on the dimensions of the scale could be arranged in descending order. The managers' fear of negative feedback was in the first order, followed by the fear of the negative reactions in the second order, Regulatory and administrative policies) in the third position, followed by (weak communication opportunities) in the fourth ranking, and finally came (after the support of senior management of organizational silence) in the last ranking.

3- There are no statistically significant differences between the sports specialists working in the directorate of youth and sports, and the sports specialists working in the National Sports Council, in the degree of their response to the dimensions of the measure of organizational silence, as well as the total score of the scale.

4- There are statistically significant differences among the sports specialists working in the governmental sports organizations, in the degree of their response to the dimensions of the organizational silence scale according to gender (males females) in favor of males in all dimensions of the scale, as well as on the total score of the scale.

5- There are statistically significant differences between the sports specialists working in the governmental sports organizations, in the degree of their response to the dimensions of the organizational silence scale according to the years of experience (third degree second degree first degree - large).

6- There are statistically significant differences between the sports specialists working in the governmental sports organizations in the degree of their response to the dimensions of the organizational silence scale according to the level of education (BA MA - PhD).

7- All dimensions of organizational silence have a contribution rate in the total score of the measure of organizational silence of sports specialists working in government organizations.

\section{Recommendations:}

1-Developing the positive values of the managers towards the silence of the employees and the importance of reducing the silence of their organizations, and the awareness of the importance of listening to the problems of employees and their views, and their participation in decision-making.

2-Organizing training courses for managers to develop democratic leadership skills and participatory leadership, and raise awareness of the importance of participation in decision-making.

3-Organizing the training courses for both managers and sports specialists on the skills of effective communication and its positive role in the development of communication between employees at different administrative levels.

4-Promote the principles of trust between employees and their superiors by encouraging them to submit their proposals and to enhance their constructive participation.

5-Organizing the training courses that deal with the content of the regulations and laws governing the work of the governmental organizations so that all employees from different administrative levels can understand their contents and know their details well.

\section{References:}

1-Abdullah Mohammed Al-Wahaibi (2014): "The impact of the prevailing climate in the government departments in Al-Qassim area The Organizational Silence, "Jordanian Journal of Business Administration, No. (3), Vol. (10 ) (P. 74). 
2-Abdul Mohsin Abdul Mohsen (2013): "Assets Management -2", University House, Mansoura, p. (33).

3-Ahmed Abdel Salam Selim (2012): "Behavior of organizational silence a comparative study between companies sector Public and Private Business in Egypt ", Scientific Journal of Economics and Trade, No. (3) Vol. 2, p. 446,447)

4Akın,U. \& Ulusoy.T.(2016):" The Relationship between Organizational Silence and Burnout among Academicians: A Research on Universities in Turkey.", International Journal of Higher Education, Vol. (5), No. (2), pp.(45-58).

5-Alaa Ahmed Omran (2016): "the relationship of organizational confidence in the behavior of the silence of workers on critical issues Applied Study on Governmental Sector Hospitals in Delta Governorate ", Master Thesis, College Trade, University of Menoufia, p (42)

6Altinkurt, Y.(2014):" The relationship between school climate and teachers' organizational silence behaviors", Anthropologist journal, Vol.( 18),No. (2), pp. (289-297).

7-Amal Yassin Majali (2007): "The impact of organizational silence in the decision-making process a field study Analysis of Jordanian public institutions. ", Ph.D., Faculty of Financial and Administrative Studies , Amman Arab University for Graduate Studies.

8 Amira Ahmed Ibrahim (2015): "The impact of organizational silence on the effectiveness of administrative decisions by applying to Directorate of Education, Dakahlia Governorate, "Master Thesis, Faculty of Business Administration, University Tanta, p.

9Bagheri, G., Zarei,R.\& Nik,M.(2012): "Organizational Silence(Basic Concepts and Its Development Factors)",Ideal Type of Management Journal ,Vol . (1), No . (1), PP. (54).

10Beheshtifar, M. , Borhani,H., Moghadam, M.,(2012): "Destructive Role of Employee Silence in Organizational Success.", International Journal of Academic Research in Business and Social Sciences, Vol. (2), No. (11),pp.(277-278).

11Bogosian, Robert.(2012), "Engaging Organizational Voice: A Phenomenological Study of Employee's Lived Experiences of Silence in Work Group Settings", Master degree, The Faculty of Education and Human
Development of the George Washington University ,pp.(155).

12-Dankoski, M., Bickel, J., Gusic, E.(2014):" Discussing the undiscussable with the powerful: Why and how faculty must learn to counteract organizational silence", Academic Medicine, Vol.(89) ,No. (12) , pp. (1610-1613).

13Detert,j.,Trevino,1.(2010):"Speaking Up to Higher Up:How Super Visors and Skip-Level Leaders Influence Employee Voice.", Organizational Science, Vol. (21), pp. (249270).

14-Harbalioğlu, M., İnce, B.(2014):" The Relationship between Organizational Silence and Organizational Citizenship BehaviorA Case Study at Kilis 7 Aralik University" International Journal of Advances in Management and Economics Vol.(3), No.(2).pp.(156).

15Hasani,T., Sharifian,L. Sousahabi, P. (2016):"Relationship between Leadership Styles and Organizational Silence in Educational And Administrative Staff of Second Period Secondary Schools in Islamshahr",Turkish Journal of Psychology,Vol (31) No (77), PP. (49).

16-Henriksen, K., Dayton, E.(2015):" Organizational silence and hidden threats to patient safety", Health Services Research, Vol.(41) pp(39-54)

17Kahveci, G., Demirtaş, Z.(2014):"School administrator and teachers' perceptions of organizational silence [Okul yöneticisi ve öğretmenlerin örgütsel sessizlik algilari]", Egitim ve Bilim,Vol.( 38),No. (167), pp.( 5064).

18Knoll,M.\&Dick,R.( 2013):"Do I Hear The Whistle ? A first attept to measure four forms of employee Silence and their correlates . ", Journal of Business Ethice, Vol. (13), No.(2),pp. (350).

19koustiuk,D.(2012):"The Reasons ,Why People may not Communicate .",Ph.D., University of MissouriColumbia,PP.(40).

20-Leyva-Moral, J.(2015):" Organizational silence. Reasons and implications of silence in the workplace: A literature review [Silencio organizacional. Revisión bibliográfica de las razones y consecuencias del silencio en el trabajo]", Index de Enfermeria, Vol.(16),No. (57) .

21 -Milad Mohammed Milad (2015): "The impact of organizational silence on the stages of decision-making an applied study on University of Sirte, Libya ", Master's Degree, Department of Business Administration, Faculty of Commerce, University of Libya. 
22-Morrison,E., Wheeler-Smith,S.,Kamdar,d., (2010):"Speaking up Groups:An cross-Level Study of Group Voice Climate and Voice." Journal of Applied Psychology, Vol. (8), No.(6),pp. (120).

23 -Nihal Mohammed Rabie (2014): "The impact of organizational silence on the attitudes of workers towards change.", Master Thesis, Faculty of Commerce, Tanta University, p. (33).

24-

Nikmaram,S.,Yamachi,H.,Shojaii,S.,Zahrani,M.,\&Alvany, S.(2012):" Study on Relationship Between Organizational Silance and Commitment in Iran.",World Applied Sciences Journal, Vol. (17), No.(10),pp. (1230).

25Park,C.,Keil,M.,(2009):" Organizational Silance and Whistle-Blowing on it Project:An integrated Model."Decision Science, Vol. (40), pp. (910 918).

26Robbins,s., Judge,t.,(2013)"Organizational Behavior", Pearson, Cloth,

15th Edition,New Jersey,PP.(300).

27Shawki Mohammad Al-Sabbagh (2010): "Determining the silence of workers on important work issues and their reflection on Job Satisfaction An Empirical Study on the Agricultural Development and Credit Bank ", Journal of
Studies Commercial, University of Menoufia, No. $(3,4), \mathrm{p}$ (114).

28Shojaie, S., Matin, H.Z., Barani, G.(2011):"Analyzing the infrastructures of organizational silence and ways to get rid of it", Procedia -Social and Behavioral Sciences, Vol.( 30), pp. (1731-1735).

29Tülübaş, T., (2011):" Öğretim elemanlarının sessiz kaldıkları durumlar ve sessiz kalma nedenleri [Silence of faculty members: issues and causes of silence]"., master's thesis, Kocaeli University Graduate School of Social Sciences, Kocaeli.

30Yurdakul, M., Beşen, M., Erdoğan, S.,(2016):" The organisational silence of midwives and nurses: Reasons and results", Journal of Nursing Management , Vol.(4),No.(6).

31-Zaynab Abdel Razek Aboud, Zafar Nasser Hussein (2016): "The causes of organizational silence and its impact on performance staff. ", Journal of the University of Babylon for Pure and Applied Sciences, No. (1), Volume (24), p. (240)

32Zehir,C.\&Erdogan,E.( 2011):"The association between organization silence and ethical leadership through empioyee performance.", Journal of Procedia Social Behavioural Sciences, Vol. (24), pp. (1390). 